\title{
解析准一维钙铁矿硫系化合物中的二向色性转换
}

\author{
吴江滨 ${ }^{1}$, 谭平恒 ${ }^{2,3^{*}}$, 汪涵 ${ }^{1,4^{*}}$
}

1. Ming Hsieh Department of Electrical and Computer Engineering, University of Southern California, Los Angeles, CA 90089, USA;

2. 中国科学院半导体研究所, 半导体超晶格国家重点实验室, 北京 100083;

3. 北京量子信息科学研究院, 北京 100193 ;

4. Mork Family Department of Chemical Engineering and Materials Science, University of Southern California, Los Angeles, CA 90089, USA

* 联系人, E-mail: phtan@semi.ac.cn; han.wang.4@usc.edu

\section{Linear dichroism conversion in quasi-1D perovskite chalcogenide}

\author{
Jiangbin $\mathrm{Wu}^{1}$, Ping-Heng $\operatorname{Tan}^{2,3^{*}}$ \& Han Wang ${ }^{1,4^{*}}$ \\ ${ }^{1}$ Ming Hsieh Department of Electrical and Computer Engineering, University of Southern California, Los Angeles, CA 90089, USA; \\ ${ }^{2}$ State Key Laboratory of Superlattices and Microstructures, Institute of Semiconductors, Chinese Academy of Sciences, Beijing 100083, China; \\ ${ }^{3}$ Beijing Academy of Quantum Information Sciences, Beijing 100193, China; \\ ${ }^{4}$ Mork Family Department of Chemical Engineering and Materials Science, University of Southern California, Los Angeles, CA 90089, USA \\ *Corresponding authors, E-mail: phtan@semi.ac.cn; han.wang.4@usc.edu
}

doi: 10.1360/TB-2019-0280

光的二向色性是指自然或人造晶体中沿着不同晶向 对线偏光吸收的差异. 通过设计优化人造晶体中的微/纳 米结构可以获得很强的二向色性, 可用在起偏器和半波片 等光学组件中. 在自然晶体中, 二向色性通常来源于晶体 中的低对称性, 而这与晶体结构和元素组成有很大关系. 这些各向异性晶体同样可以用于改善传统光学元件的性 能, 也可以用做线偏振敏感的光子器件. 这类器件是许多 新兴的传感和通信应用的重要组成部分.

具有光学各向异性的材料通常具有较低的晶体对称 性水平, 其通常存在于低维晶体中, 例如二维材料或一维 材料 ${ }^{[1,2]}$. 二维材料以层状黑磷 (BP)为代表, 而一维材料则 以碳纳米管为代表. 然而, 在这些材料中, 二向色性的极 性在非常宽的波长范围内是统一的, 即沿某一个晶向的光 的吸收总是强于沿其他方向的光吸收. 最近, 研究人员在 包括 $\mathrm{BaTiS}_{3}$ 和 $\mathrm{Sr}_{1-x} \mathrm{TiS}_{3}$ 在内的三元钻钛矿硫属化物中, 在 中波红外和长波红外波段观测到了显著的光学各向异性. 在这些材料中, $\mathrm{TiS}_{6}$ 八面体形成了平行的准一维晶链, 如 图 1(a), (b)所示. 而链内和链间方向之间的结构和化学组 成的显著差异, 导致了中波红外和长波红外波长范围内的 很强的二向色性 ${ }^{[3 \sim 5]}$.

最近, 本课题组 ${ }^{[6]}$ 揭示了准一维 $\mathrm{BaTiS}_{3}$ 中独特的二向 色性转换现象, 相关成果已在 Advanced Materials 发表. 我 们在可见光波段内观察到了极大的二向色性, 更加有趣的 是, 二向色性的极性在 $1.78 \mathrm{eV}$ 附近发生了转换. 密度泛函
计算结果表明, 这种二向色性转换起源于 $\mathrm{BaTiS}_{3}$ 中的平行 能带导致的联合态密度奇点, 两类具有不同偏振特性的奇 点对应的能量不同, 呈现在吸收谱上就是二向色性的极性 转换. 此外, 我们也通过不同波长的偏振拉曼光谱再次印 证了这种二向色性的转换现象.

为了确定 $\mathrm{BaTiS}_{3}$ 的晶体结构的各向异性(图 1(a), (b)), 我们用高分辨 TEM 对其进行了表征. 如图 1(c), (d)所示, 垂直于准一维晶链的截面呈六角结构, 而平行于准一维晶 链的截面则呈四方结构, 证明了准一维晶链的存在. Ba$\mathrm{TiS}_{3}$ 在可见光范围的偏振吸收谱给出了其二向色性转换的 直接证据. 如图 1(e), (f)所示, 当光子能量小于 $1.78 \mathrm{eV}$ 时, 沿着 $Y$ 方向的吸收远大于沿着 $X$ 方向的吸收; 而当光子能 量在 1.75 2.15 eV 之间时, 沿着 $X$ 方向的吸收远大于沿着 $Y$ 方向的吸收, 这说明 在 $1.78 \mathrm{eV}$ 附近, 二向色性发生了 转换. 为了体现二向色性的强度, 我们定义了线偏极化度 (DLP $=\left(A_{y}-A_{x}\right) /\left(A_{x}+A_{y}\right)$, 其中 $A_{x}$ 和 $A_{y}$ 分别为沿着 $X$ 和 $Y$ 方 向的吸收强度). DLP 的值域为 $[-1,1]$, 其符号为负表示沿 着 $X$ 方向极化, 符号为正表示沿着 $Y$ 方向极化, 绝对值越 大极化强度越大. 结果表明, 在光子能量为 $1.70 \mathrm{eV}$ 的位置, DLP 达到了 0.9, 在晶体材料中这是一个非常大的数值. 同 时, 显而易见地, DLP 在 $1.78 \mathrm{eV}$ 附近发生了符号变化, 对 应二向色性的转换.

密度泛函计算结果表明, 这种二向色性转换起源于 $\mathrm{BaTiS}_{3}$ 中的平行能带导致的联合态密度奇点, 两类具有不 
(a)
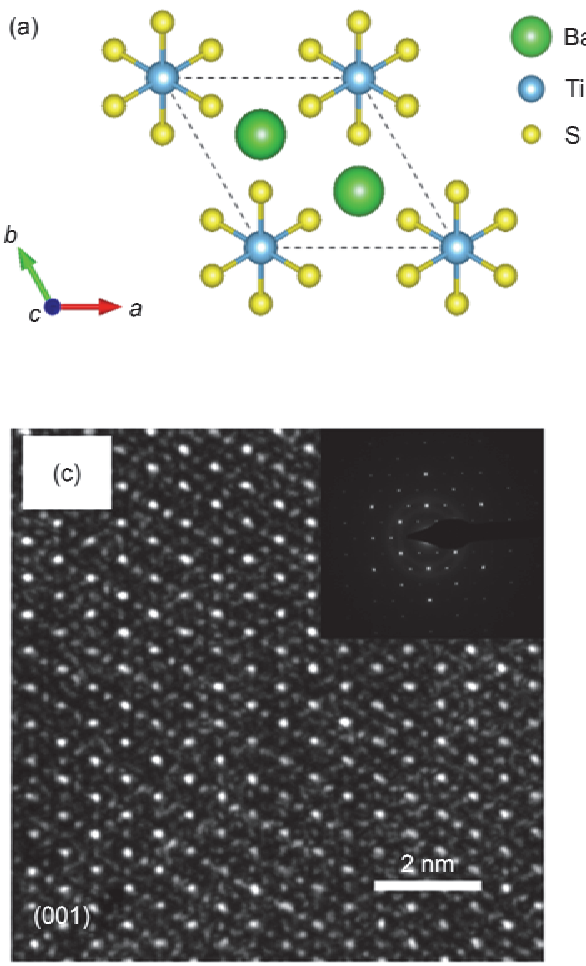

(e)

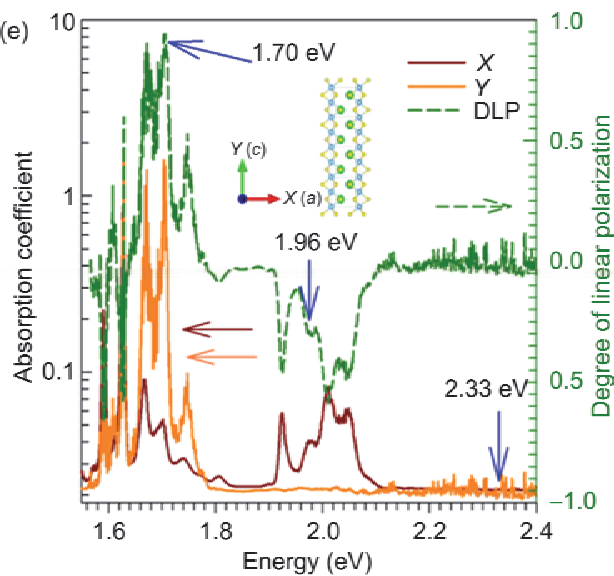

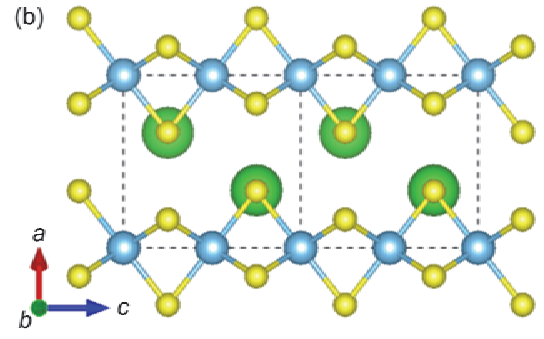
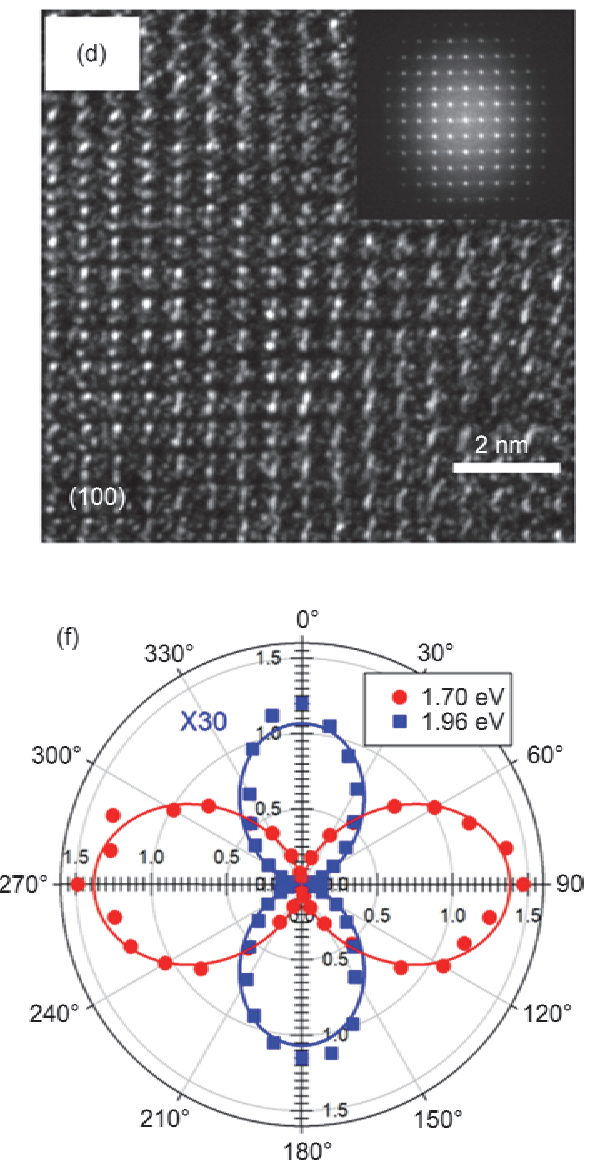

图 1 (网络版彩色) $\mathrm{BaTiS}_{3}$ 的晶格结构. (a) 沿着 $c$ 轴, (b) 沿着 $a$ 轴. (c) 图(a)中对应的高分辨透射电子显微镜(TEM)图像, 呈六角结构. (d) 图(b)中对应的高分辨 TEM 图像, 呈四方结构. (e) 偏振(分别沿 $X$ 和 $Y$ 方向)吸收谱和线偏极化度(DLP). (f) 不同波长下吸收强度随 人射角度的变化

Figure 1 (Color online) Lattice structure of the $\mathrm{BaTiS}_{3}$ lattice viewed along (a) the $c$-axis and (b) the $a$-axis of the crystal. Atomic resolution TEM imaged along (c) the $c$-axis and (d) $a$-axis of the $\mathrm{BaTiS}_{3}$ crystal. (e) Absorption coefficients in response to the $X$ - and $Y$-polarized beam and the degree of linear polarization (DLP) in the visible range. (f) Polar plots of the absorption coefficients with changes in the incident beam polarization angle at two different excitation photon energies of 1.70 and $1.96 \mathrm{eV}$, respectively

同偏振特性的奇点对应的能量不同, 从而形成了二向色性 的转换. 如图 2(a)所示, 沿着晶格 $a$ 和 $b(X)$ 方向有 3 个比较 锐利的吸收峰, 分别位于 $1.15,1.6$ 和 $2.33 \mathrm{eV}$, 而沿着 $c(Y)$ 方向在 $2.0 \mathrm{eV}$ 附近有一个吸收峰. 因为这些吸收峰对应的 是平行能带之间的跃迁, 如图 2(b)所示, 所以其峰宽都比 较窄, 从而导致了二向色性的转换. 为了进一步证明, 我
们测量了 $\mathrm{BaTiS}_{3}$ 的多波长的偏振拉曼光谱, 如图 2(c), (d) 所示. 选取了 3 个不同的波长，分别是处于无二向色性的 波段 $(2.33 \mathrm{eV})$ 、二向色性极化沿着 $X$ 方向的波段 $(1.96 \mathrm{eV})$ 和二向色性极化沿着 $Y$ 方向的波段 $(1.71 \mathrm{eV})$. 在 $2.33 \mathrm{eV}$ 的 激发光下, 由于没有二向色性, 拉曼的偏振特性(极化沿着 $Y$ 方向)由声子模式的拉曼张量决定. 而在 $1.71 \mathrm{eV}$ 的激发 

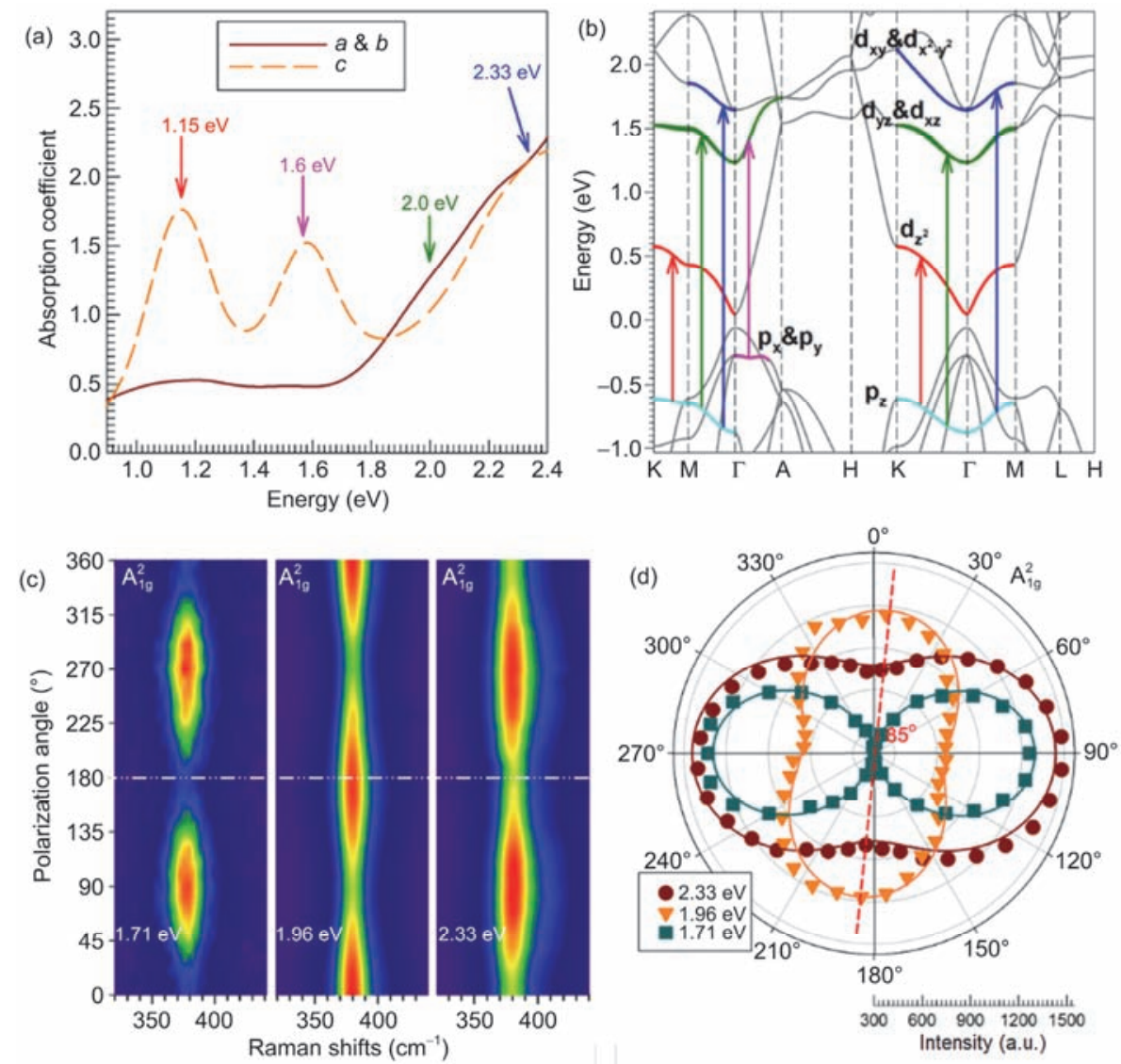

图 2 (网络版彩色)密度泛函计算的偏振吸收谱(a)和其中的吸收峰在能带结构中对应的跃迁(b). (c) 不同波长下的偏振拉曼光谱. (d) 在 不同波长下拉曼峰的强度随着人射光偏振角度的变化

Figure 2 (Color online) The absorption spectra calculated using DFT for excitation light polarized along $c$-axis and $a(b)$-axis (a), and the theoretically calculated band structure (b). (c) Anisotropic Raman spectra for the three excitation conditions at 1.71, 1.96, and 2.33 eV. (d) Polar plots of the Raman spectra intensity versus the polarization angle at the $2.33,1.96$, and $1.71 \mathrm{eV}$ excitations

光下, 拉曼强度的极化也是沿着 $Y$ 方向, 但是极化强度明 显大于 $2.33 \mathrm{eV}$ 时的极化强度, 这是由于沿着 $Y$ 方向极化 的二向色性的加成作用. 而在 $1.96 \mathrm{eV}$ 的激发光下，拉曼强 度的极化几乎是沿着 $X$ 方向的, 因为这时二向色性的极化 是沿着 $X$ 方向的, 从而影响了拉曼光谱偏振极化的取向.
总之, 我们通过吸收谱、理论计算和拉曼光谱三个手 段相结合证明了在钻钛矿硫族化合物 $\mathrm{BaTiS}_{3}$ 中存在着二 向色性极性的转换. 这样的特性使得 $\mathrm{BaTiS}_{3}$ 可用于实现波 长敏感的偏振光子器件, 并且将来有可能应用于光通信、 成像和传感等多个领域.

\section{推葆阅读文献}

1 Wu J B, Lin M L, Cong X, et al. Raman spectroscopy of graphene-based materials and its applications in related devices. Chem Soc Rev, 2018, 47: 1822-1873

2 Zhang X, Qiao X F, Shi W, et al. Phonon and Raman scattering of two-dimensional transition metal dichalcogenides from monolayer, multilayer to bulk material. Chem Soc Rev, 2015, 44: 2757-2785

3 Niu S, Zhao H, Zhou Y, et al. Mid-wave and long-wave infrared linear dichroism in a hexagonal perovskite chalcogenide. Chem Mater, 2018, 30: 4897-4901

4 Niu S, Joe G, Zhao H, et al. Giant optical anisotropy in a quasi-one-dimensional crystal. Nat Photon, 2018, 12: 392-396

5 Niu S, Huyan H, Liu Y, et al. Bandgap control via structural and chemical tuning of transition metal perovskite chalcogenides. Adv Mater, 2017, 29: 1604733

6 Wu J, Cong X, Niu S, et al. Linear dichroism conversion in quasi-1D perovskite chalcogenide. Adv Mater, 2019, $31: 1902118$ 